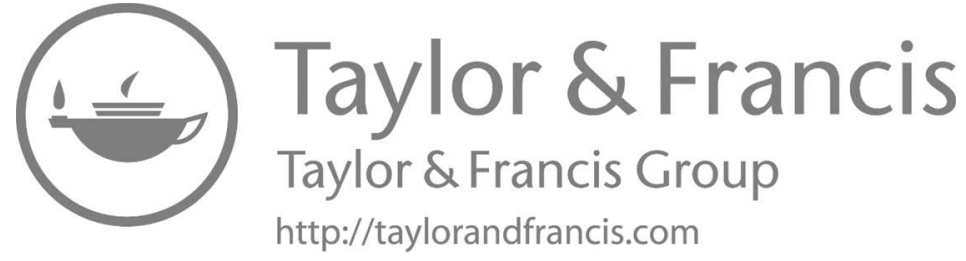




\title{
FACING THE PANDEMIC
}

\section{Italy's functional 'health federalism' and dysfunctional cooperation}

\author{
Elisabeth Alber, Erika Arban, Paolo Colasante, \\ Adriano Dirri and Francesco Palermo ${ }^{1}$
}

\subsection{Introduction}

Italy was severely affected by the Covid-19 pandemic, with a disproportionately high number of infections and an even higher mortality rate (due to the large number of elderly people who died). As of 31 October 2020, 709,335 people in a population of about 60 million had been infected, with 38,826 fatalities. The impact of the first wave of infection was extremely uneven across Italy's territories, with most of the cases concentrated in a handful of urbanised and industrialised regions in the north of the country. In the second wave, in autumn 2020 , the prevalence of the virus was instead more evenly distributed among the territories.

When the pandemic reached the country in January 2020, Italy's hybrid territorial set-up, falling in between a fully fledged federal system and a unitary state, was undergoing reforms aimed at strengthening its regional and local system. Although reforms were put on hold as a result of the emergency, they succeeded in raising concerns and generating proposals for counter-reform, not least because the country's pandemic management laid three issues bare.

First, cooperation mechanisms across and within governmental levels are deficient and underutilised; secondly, while Italy's 20 regions have a wide range of powers, including over health matters, in many cases they lack the capacity to face a major crisis; and thirdly, issues of insufficient capacity also afflict the country's highly diverse and fragmented system of local government.

This chapter assesses the legal framework put in place at the national (state), the subnational (regional), and the municipal levels to face the Covid-19 emergency. It seeks to identify how different measures and actors in the management of the pandemic relate to each other and points out inconsistencies and synergies as well as their impact on Italy's asymmetric regionalism. The different responses 
by the territories revealed both the potential of the country's asymmetric territorial governance and the weaknesses of its incomplete, quasi-federal system, especially as far as the unclear division of powers and inadequacy of intergovernmental relations (IGR) are concerned.

\subsection{The constitutional and legal framework}

\subsubsection{Distribution of powers}

Italy is a regional state blending together unitary and federal features, with 20 regions being the main, though not the only, players at the subnational level. Article 5 of the Constitution promotes autonomy and decentralisation, while article 114(1) provides that, in addition to the state, Italy is composed of municipalities, provinces, metropolitan cities, and regions, all of which are 'autonomous entities having their own statutes, powers and functions'.

The regional model is asymmetrical, in reflection of the numerous socioeconomic, cultural, geographical, and other cleavages that characterise the country. Of the 20 regions, five - Friuli-Venezia Giulia, Sardinia, Sicily, Trentino-Alto Adige/Südtirol, and Valle d'Aosta/Vallée d'Aoste - have special forms of autonomy in terms of their form of government, distribution of legislative and administrative powers, and financial arrangements. These features are entrenched in their statutes of autonomy, which were bilaterally negotiated with the national government and have the rank of constitutional law (unlike the case with ordinary regions). Article 116(2) of the Constitution mandates, furthermore, that TrentinoAlto Adige/Südtirol (Trentino-South Tyrol) is composed of the autonomous provinces of Trento and Bolzano/Bozen'. Unlike other regions, in TrentinoSouth Tyrol, most powers are vested with the two autonomous provinces, and not with the region (which results in two health-care systems in one region).

A constitutional reform in 2001 sought to reduce the gap between special and ordinary regions. Article 116(3) of the Constitution, introduced in 2001, allows ordinary regions to negotiate 'additional special forms and conditions of autonomy' with the national government, something which three regions - Lombardy, Veneto, and Emilia-Romagna - have been doing. This process, known as 'differentiated regionalism', entails further regionalising powers in health matters, as a result allowing, for instance, for the possibility to tailor training courses to local needs, and for the creation and management of complementary health insurance schemes (Grazzini et al. 2019).

The division of legislative powers between the national government and ordinary regions is enshrined in article 117(2) of the Constitution, which lists powers falling within the exclusive competence of the state. Article 117(3) enumerates powers shared by the state and the regions. In shared areas, legislative powers are vested in the regions, while the fundamental principles governing these powers

are laid down in national legislation. Regions enjoy residual powers by virtue of article 117(4) of the Constitution. This division of legislative powers applies only 
to ordinary regions, since the powers of autonomous regions are spelled out in their statutes of autonomy.

In practice, regional autonomy is conditioned by the financial relations that each region or entity has with the centre. Special regions are financed differently to ordinary regions: each special region enjoys a bilaterally negotiated financial regime based on a share of state taxes referable to the territory (from 25 to 90 per cent), while ordinary regions depend largely on the centre. Such asymmetry is also reflected in how the local government level is financed: special regions in the north run local finance, whereas in Sicily and Sardinia local finance remains with the centre.

\subsubsection{Distribution of powers in health matters}

Article 32 of the Constitution protects the right to health, mandating that ' $[\mathrm{t}]$ he Republic safeguards health as a fundamental right of the individual and as a collective interest ....' Law No. 833/1978 introduced universal health coverage, providing uniform and equal access to the National Healthcare Service (NHS) (Cicchetti and Gasbarrini 2016).

The NHS is organised at national, regional, and local levels and comprises an intricate web of responsibilities. Health protection is a competence shared between the state and the regions in an arrangement in which the national government 'sets the fundamental principles and goals of the health system, determines the core benefit package of health services guaranteed across the country ... and allocates national funds to the regions' (Scaccia and D'Orazio 2020: 109). Regions, in turn, 'are responsible for organising and delivering health care' (Cicchetti and Gasbarrini 2016: 1). At the local level, local health authorities deliver community health services and primary care directly, while secondary and specialist care is delivered directly or through public hospitals and accredited private providers.

This arrangement has given rise to 21 regional health-care systems, all quite different in their effectiveness in service delivery and the efficiency with which they operate. In this regard, there is high patient mobility between regions along the north-south divide; at the same time, the national government acts as a (financial) watchdog imposing corrective policies based on a set of indicators for all those regions that are not able to guarantee the core benefit package of health services. In recent times, regions in the centre-south in particular (though not exclusively) have been subject to recovery plans that include actions to address the structural determinants of costs (Toth 2014).

Since 2001, different regions have made different choices as to their governance models in health care, models that range from the heavily centralised, such as in Tuscany, to the heavily privatised, such as in Lombardy. The latter opted for a so-called choice and competition model (Nuti et al. 2016: 18-19), while Tuscany (followed by other regions such as Emilia-Romagna, Friuli-Venezia Giulia, and Veneto) adopted a model that combines hierarchy and targets, transparent public ranking, and pay for performance (ibid: 21-2). From a substantive 
viewpoint, it has thus been argued that in the last 10-15 years, the NHS has been strongly decentralised even though this evolution is not yet recognised formally (Neri 2019: 166).

\subsubsection{Declaration of emergencies or disasters}

Italy's Constitution does not include any specific emergency provision. Article 77 allows the national government to legislate, without previous delegation by Parliament, in cases of 'necessity and urgency'. In such event, it can adopt, under its own responsibility, a temporary measure (law decree), one which needs to be converted into law by the national parliament within 60 days, otherwise it loses its validity from the outset.

The declaration of a state of emergency for public-health reasons is regulated in ordinary legislation in article 24 of the Code of Civil Protection. The Code, however, does not define the powers that the national government may exercise under a state of emergency, nor does it authorise to limit fundamental freedoms. It indicates simply the type of emergency events that can activate civil protection powers at local, regional, or state level.

In the case of Covid-19, the nature of the threat required the use of national civil protection powers. The head of the Civil Protection Department (CPD) was vested with the power to issue special orders in derogation of any current provision and in compliance with the general principles of the legal system (extraordinary ordinances of necessity and urgency) (Raffiotta 2020). While administrative in nature, these acts can derogate legislative provisions: in this way, the legal machinery was equipped to intervene at any given moment.

\subsection{Preparedness for a national disaster: The institutional framework}

In Italy, civil protection responsibilities are not assigned to a single level of government but involve the entire territorial organisation. Although the country is frequently exposed to natural hazards, the civil protection system currently in place was established only in the early 1990s. In 1992, Law No. 225 established the civil protection system, dividing its actions into three categories (article 3): forecasting and prevention, relief and assistance, and management of state of emergency and recovery programmes.

Since its inception, the civil protection system has been an integrated one based on the principles of vertical and horizontal subsidiarity and thus entailing the involvement of all governmental levels and many actors across, within and beyond levels (with a highly mobile force of volunteers). Within the civil protection system, regions and local governments, acting in terms of national framework regulations, formulate and implement their own emergency programmes and transmit data to the CPD as the operative arm of the national government. In 2010, the Organisation for Economic Co-operation and Development 
(OECD) gave this decentralised system a positive evaluation, especially in regard to monitoring risks and providing efficient first-on-site response actions in case of earthquakes. However, in terms of health-related emergencies, in the absence of any major emergency in the past five decades prior to Covid-19, Italy has not been put to the test and its authorities have neglected to update their pandemic plans.

At a national level, the CPD was consequently forced to implement the 2006 national plan against pandemics when Covid-19 entered the scene. Unlike other European Union (EU) member states, Italy's authorities failed to update their pandemic plan in 2017 when the World Health Organization (WHO) and European Centre for Disease Prevention and Control issued new guidelines. Regional health authorities were forced to apply outdated regional pandemic plans to the best of their knowledge.

Though it differed in extent from one region to another, this lack of preparedness - rather than decentralisation - compromised the effectiveness of responses to the emergency in the first half of 2020. Resources to face the pandemic were missing (for instance, personal protective equipment), as were risk-prevention protocols in care facilities and the capacity for mass testing and contact tracing. Intergovernmental data-sharing was, and remained, deficient; different territorial systems were, and remained, poorly interconnected and coordinated. All of these issues triggered off various quarrels between the north and south and eventually turned into an intense political battle, one in which the weak coalition government became entrammelled and which cast its shadow over regional politics.

\subsection{Rolling out measures to contain the pandemic}

\subsubsection{Taking the initiative}

Caught unprepared, Italy followed an incremental 'mitigation path' rather than a 'containment path' in its pandemic management. It tried to dampen the pandemic's impact on the health system and the resultant mortalities within a territorial system that, thanks to political gamesmanship, typically does not benefit much from intergovernmental institutional learning capabilities. Overall, Italy's pandemic response was impaired chiefly by three issues: first, the national government's moderate to low capacity to implement its decisions collaboratively and launch relief and recovery packages speedily; secondly, incoherent policy-making tenuously based on evidence; and thirdly, deficient IGR structures (Capano 2020: 327-30).

Although experts had been warning of the severity of the coronavirus outbreak since the beginning of the year in 2020, the national government was unable to contain the virus whilst it was still in its infancy. It was only from early March 2020 - following the recommendations of the National Health Institute (NHI) and an ad hoc expert committee formed on 5 February including the president 
of the NHI - that a flood of measures were adopted at the national level. The expert committee was to be supplemented several times with further experts, in addition to which its gender representation was improved (initially it was maleonly). Numerous other taskforces were also established in individual ministries and at the subnational level.

From 18 March 2020, a special commissioner appointed by the national government coordinated all actions. For instance, until the end of April, the expert committee had been setting the standard for how tests were administered (for instance, only to persons with symptoms). This was considered controversial. The policy of the Veneto region at that point was to opt against such an approach in favour of mass testing and tracing (Lavezzo et al. 2020). In hindsight, Veneto is an example of how regional organisational autonomy in health care played out well in comparison to other regions such as Lombardy (even though the latter was under the same regional party-political leadership). Generally, pandemic management was, from the outset, caught up in a blame game between the national government and the opposition, one that unfolded in the context of an already volatile political situation.

Following the 2018 general elections, the anti-establishment party, the Five Star Movement (M5S), and the populist League (Lega per Salvini Premier, headed by Matteo Salvini), agreed on a government programme led by the independent Giuseppe Conte, who had never before held political office. After months of internal bickering, the ill-fated coalition government broke down when Salvini, in early August 2019, withdrew the League from the alliance and called for a snap election with the aim of becoming Prime Minister. The M5S, however, teamed up with the Democratic Party (PD), and in less than a month the new coalition government, again under the prime ministership of Giuseppe Conte, was sworn in.

It fell to this alliance, composed by traditionally staunch rivals, to navigate through the 2020 pandemic year, with polls showing an increase in popular support for centre-right parties. The second half of 2019 had suggested how fractious this alliance was - as part of the coalition government, former Prime Minister Matteo Renzi, elected in 2018 with the PD, left the PD in mid-September 2019 to form his own party, Italia Viva. Throughout autumn 2020, dissenting opinions on how to manage the pandemic and the resources connected to the EU Recovery Fund continued to weaken the coalition government, one which, in essence, managed the pandemic by decree while stressing that all measures taken were based on the recommendations of experts - a reading of the expert committee's protocols shows, however, that many of its recommendations were disregarded. At the beginning of the new year, a new crisis within the government arose, whose consequences have been the end of the second Government of Giuseppe Conte, succeeded by Mario Draghi, supported by almost all political parties in the Parliament.

Policy responses at regional level were likewise informed by volatile political dynamics. Some regions took the lead in clearly voicing their strategies to 
contain the pandemic and its impact; however, party allegiances alone were not an indicator or predictor of how effective (or ineffective) the strategies adopted were. Generally, many factors determine to what extent regional (and local) governing practices are dependent on and affected by the political situation at the national level. The most important are differences in fiscal capacity; differences in health-care models and the capacities of regional administration (in the case of the pandemic in 2020); and differences in personality and character of regional political leaders (all except two presidents are directly elected).

After the regional elections in 2020 (Emilia-Romagna and Calabria voted on 26 January and Aosta Valley, Veneto, Liguria, Tuscany, Marche, Campania, and Puglia on 20-21 September), the centre-left held on to five regions, while the centre-right retained 14 regions (among them the autonomous province of Trento, led by the League). Aosta Valley and the autonomous province of Bolzano/Bozen are led by autonomist political parties. In brief, the September elections saw victories for those presidents who performed well during the first wave of Covid-19 infections, such as Luca Zaia in Veneto from the League.

\subsubsection{National action}

On 31 January 2020, one day after the WHO declared the Covid-19 outbreak a public emergency of international concern, the Italian government declared a state of emergency. The country's first cases of infection were reported on 17 February in two small towns in Lombardy and Veneto. At that time, the national strategy was to contain the pandemic by local ordinances. Likewise, a regional ordinance introducing quarantine measures was issued on 21 February regarding the outbreak of the coronavirus in some municipalities in Lombardy.

As the coronavirus rapidly began to spread, the national government issued Law Decree No. 6 of 23 February 2020 which vested subnational authorities with the power to 'adopt all containment and management measures that are adequate and proportionate to the evolution of the epidemiological situation' (article 1(1)). Thereafter, further decrees and ordinances by the Prime Minister, CPD and Minister of Health provided detail as to who the "competent authorities' were and what their margin of action was.

Regarding lockdowns, a series of Prime Minister's Decrees (DPCM) were issued from 23 February to 4 March 2020 with the aim of gradually tightening restrictive measures for the containment of the pandemic and providing for the isolation of the affected areas ('red zones'). These containment measures, initially limited to some municipalities, were also imposed on the residents of Lombardy and of 14 provinces in other northern regions. The nationwide lockdown was regulated by the DPCM issued on 8 and 9 March (and subsequently extended until May). It included severe travel restrictions (with exceptions for work or health-related grounds, or any exigency, always to be stated in a self-certification), a ban on outdoor gatherings, the closure of educational facilities (and transition to 
online learning), smart work procedures for the public and private sectors, and the suspension of all public events (including religious ceremonies).

The DPCM of 11 March 2020 tightened the lockdown measures, closing restaurants and the like (except for home deliveries) and retail commercial activities (except for essential ones such as grocery stores and pharmacies). As for local public transport, the decree left it to the presidents of regions to determine how they would maintain minimum essential services. On 20 and 22 March 2020, ordinances by the Minister of Health closed parks and public gardens as well as restricted exercise and sports activities (to be done individually and in proximity to one's home). The DPCM of 22 March 2020 suspended all non-essential industrial and commercial activities, while several DPCMs in March and April extended the duration of the lockdown measures until 17 May 2020, when a further DPCM lifted some of the restrictions and allowed for an incremental reopening of businesses and resumption of activities.

In regard to economic aid and relief, a first small package was adopted at the beginning of the pandemic. On 28 February 2020, the national government enacted a law decree supporting families and commercial activities with EUR 5.7 billion. Much more important was the second package, the Law Decree 'Cure Italy' of 16 March 2020, the purpose of which was to strengthen the health system and grant economic relief to families and commercial enterprises (especially in sectors such as tourism, logistics, and transportation). During the first hard lockdown, an additional law decree was issued on 6 April 2020 that supported businesses by providing loan guarantees, tax relief, and government assumption of non-market risks. Law Decree No. 19/2020 ('Relaunch Decree') of 19 May 2020 injected EUR 55 billion in support of health care, employment and the economy, and social policies. The last major act in support of the economy before autumn was Law Decree No. 104/2020 of 14 August 2020.

In autumn 2020, the national government found itself in political deadlock in deliberations over the national plans for recovery and resilience that Italy, like all EU members, had to submit to the European Commission by April 2021 as part of the requirements of the EU Recovery Fund. The national government continued to rule by decree, doing so in terms of calculations linked to a catalogue of 21 indicators, and imposed a phased lockdown policy on subnational entities that involved a shift from stricter to softer measures. The focus was on supporting the economy, with the regions given greater latitude in combating the pandemic.

\subsubsection{Regional action}

In declaring a state of emergency, the national government seized a significant extent of power from the regions or at least was formally entitled to do so. In the first half of 2020, a long list of national measures were enacted regarding the rules of the strict lockdown (from 8 March 2020) and its gradual easing (from 4 May 2020, with the lifting of the inter-regional travel ban as first measure). The roll-out of various measures at the national, regional, and local levels made it 
difficult to distinguish between the measures taken at different levels of government, not least because of the lack of coordination among all the various actors.

During an initial series of vague national measures and a proliferation of regional ordinances, the first half of 2020 was characterised by acrimony between the national government and the presidents of the regions. Many of the regional presidents issued regional ordinances aimed at imposing restrictive measures beyond those adopted at the national level, such as the clearly unconstitutional closure of regional borders in Campania, obligatory flu vaccinations in Lazio, and the closure of all educational institutions in Marche. Other examples of regional ordinances in the first phase include the identification and delimitation of red zones that were to be isolated from the rest of the regional territory for a limited period (e.g., in Emilia-Romagna, Lazio, and Abruzzo). A similar trend re-emerged in October 2020 during Italy's second wave of infections.

Both article 32 of Law No. 833/1978 (the one introducing the NHS) and articles 6, 11, and 25 of the Code of Civil Protection vest regional presidents with the power to issue ordinances in the field of civil protection whenever a health-related emergency occurs. The mayors have the same powers for their respective municipal territories under the law on local authorities (Legislative Decree No. $267 / 2000$ ). The multiple powers assigned to the regions in the field of civil protection, especially in the event of health emergencies, and the proliferation of 'insufficiently coordinated' (Baldini 2020: 985) national and regional measures, made it very difficult to ascertain who was responsible for which measures. While some regional ordinances were suspended, others with the same content were not.

The tug of war between the national government and the regions continued, increasing in April and May 2020 with the relaxation of the lockdown. Regions governed by centre-right coalitions (thus opposing the centre-left national government in Rome) and those less affected by the pandemic were especially eager to put their own spin on the rules specifying the exact timetable for easing measures (e.g., in regard to reopening bars and restaurants, or allowing visitors to access public beaches).

Calabria serves as an example: on 29 April, its president signed a regional ordinance easing the lockdown by reopening bars, restaurants, and pizzerias with outdoor-table service. The national government challenged these measures and, on 9 May, the administrative court of Calabria found in its favour, on the ground that it is the responsibility of the central authorities to identify measures to limit the spread of Covid-19, whereas regions are entitled to intervene only within the limits outlined in these national measures.

Likewise, the autonomous province of Bolzano/Bozen (South Tyrol) is noteworthy for its individuality of style. The national government intended to be the one to ease the lockdown and to allow regions to do so from 18 May 2020, but uniquely among the regions - South Tyrol jumped the gun by passing its own law on the resumption of activities (Law No. 4 of 8 May 2020) several days before then. In doing so, its provincial authorities clearly intended to demonstrate the political autonomy that their region enjoys. In November 2020, Aosta Valley followed 
suit by adopting its own regional law, which was however struck down by the Constitutional Court in February 2021, while other regions kept intervening by way of administrative measures (ordinances) rather than by passing their own laws.

Another example of dysfunctional intergovernmental cooperation is provided by the unilateral decision of a regional health authority that, in September 2020, decided to ban a professional football team of the first division from travelling to another region to play a match because a few players had tested positive for Covid-19; it thereby flouted a special protocol negotiated by the national government and the football league which regulates such cases in the interests of regular championship matches.

\subsubsection{Municipal action}

The evolution of the pandemic shows that regional and municipal ordinances are critical to tailoring containment measures to the needs of different territories (Boggero 2020: 362). After the state of emergency was declared, the national government set a centralist tone at the outset when its first law decree, No. 6 of 23 February 2020, essentially appropriated the power of local authorities to issue ordinances and attempted to regulate local government's scope of action in managing the pandemic (Cerchi and Deffenu 2020: 671). Thereafter, in March, the national government sought to introduce clarity to the regulatory chaos that had reigned since the pandemic began and individual local authorities had acted independently of the national government.

Law Decree No. 9 of 2 March 2020 established that municipal ordinances that stood in contrast with national measures were to be considered unlawful, while Law Decree No. 19 of 25 March 2020 stressed the relevance of measures issued at the central level. It also explicitly defined the area of competence of local and regional authorities. In the absence of any DPCM on the same matter and only in case of aggravated health conditions, the presidents of the regions and the mayors were granted the power to introduce additional and more restrictive measures. However, any action by local and regional authorities that could limit activities strategic to the national economy, such as the production of medicines or health-related equipment, along with any action that could compromise civil and social rights, or any action in health preventive measures at the international level, were unlawful and remained the sole prerogative of the state.

Within this regulatory framework, local authorities had little room for manoeuvre during the hard lockdown of March to May 2020, though it began to expand again as the lockdown was relaxed. Local authorities in Italy were thus insufficiently involved in pandemic management. Several scholars claimed that, in keeping with the law on local authorities (Legislative Decree No. 267/2000), local government should have been granted the power to issue ordinances 'as a matter of principle' during the emergency (Luciani 2020: 22). In terms of articles 50(5) and 54 of Legislative Decree No. 267/2000, in the event of local health emergencies, mayors can enact urgent and necessary ordinances. The 
same law also grants the mayor the power to enact ordinances acting as officer of the national government in situations when public safety and urban security are under threat (Sabbioni 2019: 304). Furthermore, article 32(3) of Law No. $833 / 1978$ also raises the possibility for mayors to adopt urgent emergency ordinances in areas that normally fall under the jurisdiction of the Minister of Health.

Examples abound of how the tug of war between local authorities and the national government unfolded. On 23 February 2020, the municipalities of the island of Ischia restricted access to the island for specific categories of citizens. On that same day, the ordinance was nullified by the prefect (De Siano 2020: $3-4)$ on the ground that municipal ordinances cannot contradict national legislation: in the absence of any specific health risk, local authorities cannot limit freedom of movement.

Another example was the ordinance of the Sicilian municipality of Messina (5 April 2020), which restricted access to the city harbour that connects the island to continental Italy - a vital route. The provision required any boat to register online 48 hours before its departure and await the municipality's authorisation to enter the harbour. The national government challenged the ordinance in the administrative court, which nullified it (Pignatelli 2020a) for violating several constitutional provisions, among them the principle of equality (article 3), personal liberty (article 13), freedom of movement (article 16), and state jurisdiction over public order, security, and disease prevention (article 117(h)-(q)). The court observed that a national emergency demands unitary management of the crisis and thus regional or local measures cannot undermine the national strategy.

In general, local actions in the first half of 2020 mainly concerned the issuance of ordinances aimed at closing public areas and ensuring social distancing. Despite centralisation, the power of municipalities was not seized entirely and, indeed, proved to be an essential part of the engine of Italy's emergency legislation (Pignatelli 2020b).

In regard to social-economic action, (in)activity at the local level showcased how unprepared local authorities were but also how much potential they hold as institutions. Solidarity and socio-economic relief measures were implemented through public-private partnerships and territorial networks that mobilised informal relationships among communities, often so in cooperation with volunteers from the Red Cross and the civil protection system. Several municipalities organised volunteers to provide basic services for persons and families hard hit by the pandemic or its consequences. Italian local government demonstrated innovativeness and cost-effectiveness in drawing on active citizenship and community volunteerism in the contribution it made to the country's pandemic response.

\subsubsection{Intergovernmental relations}

The management of the first wave of the pandemic in early 2020 was strongly centralised, mainly due to two reasons. First, capacity was often lacking at the regional and local levels of government. Secondly, the national government 
was unable to make effective use of the extant but deficient IGR mechanisms. Consultation and cooperation initiatives with regional and local authorities were rare and implemented only half-heartedly, with the lack of transparency in managing the pandemic being ill-received by the authorities of subnational governments as well as by experts and the public.

More generally, dysfunctional cooperation between levels of government is the reason that many of Italy's federalising reforms since the late 1990s remain little implemented. Given that the 1948 Constitution was silent on mechanisms of collaboration between the regions and the state, it fell to the Italian Constitutional Court (ItCC) to introduce a few such mechanisms judicially, among them the principle of loyal cooperation between state and regions (Caretti and Tarli Barbieri 2012: 384). For the ItCC, loyal cooperation should apply in areas of shared powers but also, more broadly, to all institutional relations between regions and the state (Judgment No. 242/1997), the aim being to limit conflict and solve complex governance issues collaboratively both in ordinary and extraordinary times. Decisions taken by the national government that are based on a merely formal consultation with the regions are illegitimate (Judgment No. 246/2019).

The principle of loyal cooperation, eventually entrenched in article 120(2) of the Constitution in 2001 and confirmed as a core principle by the ItCC in many rulings, is embodied in a system of intergovernmental conferences. These are consultative bodies for meetings of the regional presidents, the presidents of the autonomous provinces of Trento and Bolzano, and the Prime Minister (who chairs it), or competent regional and national ministers. The conferences were introduced to compensate for the fact that the Italian Constitution does not provide for a federal second chamber: the national parliament is bicameral (Chamber of Deputies and Senate), but the Senate does not function as a typical 'federal' upper chamber, since it does not represent regions or other territorial autonomies. Over the past few decades, a number of proposals have been advanced to change the Senate into a 'regional' chamber, but to no avail.

During the first wave of the pandemic, the 'Permanent Conference for the relations among state, regions and autonomous provinces' (Permanent Conference), created in 1983 and regulated by law in 1988, met even less frequently than usual and could not serve as a viable body for negotiating policies (Cortese 2020: 5). Empirical evidence shows that in the first half of 2020 neither the state nor the regions adhered properly to the principle of loyal cooperation. They did not make the best use of the Permanent Conference to coordinate responses to the pandemic. Regulatory chaos and court litigation were the consequences. Wisely, however, the national government never appealed to article 120 of the Constitution which enables it to 'act for bodies of the regions, metropolitan cities, provinces and municipalities ... in the case of grave danger for public safety and security'.

During the second wave of the pandemic, the use of the Permanent Conference became much more frequent, even though the regions preferred to resort as far and often as they could to bilateral relationships with the national 
government while, for its part, the national government continued to rule by decree. Regional presidents maintained a stance in favour or against the central government mainly on the basis of their financial dependence from Rome and their leadership capacity within the region. This in part explains why even those regions governed by the same political leadership approached both IGR and regional management of the pandemic so very differently.

\subsubsection{Intergovernmental fiscal relations}

Although the full impact of the pandemic is yet to be reckoned, the dangerous 'scissors effect' of rising expenditure and falling revenues in subnational financing is significant. What is more, when the pandemic struck Italy, the south of the country had not yet recovered from the effects of the 2008 financial crisis: the gross domestic product (GDP) was still substantially lower than before the financial crisis, given that since 2008 the economy had entered a recession with plummeting productive capacity, employment levels, and consumer demand.

Thus, although the south experienced a less severe health emergency in early 2020 than the north, the impact of the pandemic on household incomes, factoring out government support, was larger there than in the north. In addition, unemployment in 2020 grew more in the south than in any other part, with disastrous consequences for all those unable to profit from governmental relief packages because they were engaged in the informal economy that is typical of Italy's south (Banca d'Italia 2020). When the second wave of infection hit the south, the economic impact was even more devastating than in the first wave.

The Association of Italian Municipalities developed three scenarios for the loss of revenue among municipalities, with the high-risk scenario entailing a projected drop of almost 21 per cent compared to 2019 and consequences that cause severe recovery difficulties for all economic sectors (ANCI 2020). The low-risk scenario with a drop of 9 per cent compared to 2019 was projected in case of a relatively rapid exit from the emergency starting in May 2020, while the medium-risk scenario was associated with a drop of 14 per cent. Regional governments faced significant financial difficulties too, as most of their expenditure was concentrated on health (85 per cent on average) while at the same time they lost much of their income from the regional tax on productive output (IRAP), the regional surtax on personal income tax, and the regional tax on vehicles. In health matters, concerted policy-making between central and regional governments has decreased significantly in recent years, as a result of which health systems have been under-financed compared to those in central and northern European countries (Neri 2019: 158).

The case of the health-care system in Calabria, which has been subject to a recovery plan for more than a decade, is an example of the deficiency of intergovernmental fiscal relations in health governance. The special commissioner nominated by the national government failed to implement basic aspects of the centrally directed regional Covid-19 mitigation strategy (such as collecting 
accurate data on hospital beds, one of 21 indicators on which the national government based its regionally differentiated lockdown policy in autumn 2020). The pandemic could not but worsen Calabria's financial dependency on the state, with the situation clearly showing how dysfunctional cooperation was between different levels of government.

Under these kinds of circumstances, most subnational governments were unable to fulfil costly responsibilities in pandemic management on their own and became more dependent on the state. The national government set up technical committees to monitor the pandemic's effects on the adequacy of revenue to cover the expenditure needs of subnational governments. These committees assisted the national government in deciding how best to provide additional funds to subnational governments - such funds had no conditions attached to them other than the requirement of extra accountability and transparency in their management.

More generally, it is important to stress that in Italian intergovernmental fiscal relations, central authorities retain considerable control over financial resources. In health matters, complex negotiations between the national government and regional authorities normally determine financial allocations to the regionalised health-care systems, with the allocations channelled through the National Health Fund (NHF) and the national government discussing its proposal in the Permanent Conference. Basically, the national government annually allocates to the regions a budget for the provision of health-care services by calculating the essential assistance levels in the budget law on the basis of a population-based formula only partially weighted by demographic factors and the health status of the population.

The total amount of resources to be allotted to the NHF is calculated initially, then split up among the regions after they have been heard. On average, the capitation rate represents 97 per cent of the total health-care resources available to regions, while the remaining 3 per cent of resources are made up by the regional systems through own-source funding, including fees paid by patients and co-payments for specialised treatments. Local health units are funded mainly through capitated budgets, albeit in the absence of clear guidelines applicable throughout the country. Funding schemes for special regions differ to a certain extent from these arrangements (Balduzzi and Paris 2018).

No systematic datasets are available yet to shed light on how effective the 2020 relief and aid packages were. Evidence based on observation and scattered (ministerial) documentation, however, suggests they were so only to a very limited extent. The main reasons for this are, first, that bureaucratic obstacles hindered speedy processing of applications and provision of aid, with these obstacles compounded by corruption scandals and the lengthy court proceedings to which they gave rise; secondly, the national government tried to navigate the crisis in a short-term, ad hoc way by adopting small relief packages rather than bigger ones that would support Italy's subnational authorities and their very different economies in a more holistic manner. 
By and large, the effects of the pandemic on subnational financing and fiscal relations were shaped by five factors (OECD 2020: 16). First, the degree of decentralisation and spending responsibilities: intergovernmental fiscal relations in Italy are characterised by a centralised tax system and a significant decentralisation of spending responsibilities. This gives rise to a noteworthy vertical fiscal gap that applies to both the local and, above all, the regional level. Resources in 'health federalism' are channelled to regions through their own tax revenues, shares of national taxes and national equalisation transfers sustained by central value-added tax (VAT) revenue. Given that the regions have markedly different fiscal capacities, and that health care varies widely across the country, equalisation is crucial. Secondly, the characteristics of subnational government revenue: subnational governments in Italy rely heavily on grants and subsidies.

The remaining three factors to which the OECD points when addressing the territorial impact of the pandemic are the ability of subnational governments to absorb exceptional stress ('fiscal flexibility'); the fiscal health conditions of subnational governments; and the scope and efficiency of support policies. Empirical evidence shows that all these factors were highly compromised in Italy, a state which for the past 10 years had suffered from severe fiscal consolidation measures and in which the debt burden (reaching 134.8 per cent of GDP in 2019) has been posing serious constraints on government public spending and on the implementation of expansionary fiscal reforms.

\subsection{Findings and policy implications}

When the Covid-19 pandemic hit Italy, the country was about to celebrate the 50th anniversary of the establishment of ordinary regions - special ones having been in place since 1948. With the powers of the regions having been enhanced by reforms over the course of more than seven decades, the time was ripe for reconsidering Italy's territorial structure. In this regard, three sizeable and politically and economically strong regions in the north - Lombardy, Veneto, and EmiliaRomagna - were about to conclude agreements with the national government on the transfer of additional legislative powers (and related funds) in a long and significant list of areas, one ranging from environmental protection to education, from airports to labour security and protection, and from foreign trade to disaster management, among other things. The process was stalled by the pandemic - but, ironically, these regions were the worst affected by it, which raised the question of whether greater regional autonomy is indeed desirable or not (Malo 2020).

Finally, in September 2020 a national referendum endorsed a constitutional reform that reduces the size of both chambers of the national parliament by onethird, thereby further limiting the already feeble link between the Senate and the regions and making it politically more difficult to table a reform that transforms the Senate into a chamber of regional representation - a proposal that, as noted above, has been on the agenda unsuccessfully for decades. 
The pandemic is likely to impact strongly on these ongoing reform processes. It is too soon to tell what its institutional consequences will be, particularly given that at the time of this writing Italy was still in the midst of an unfolding health and economic emergency. Nor is it possible to say whether a more centralised or more decentralised structure of the country would have led overall to better or worse management of the pandemic, since performance varied markedly among the regions. It is certainly the case, however, that the emergency revealed the main weaknesses of the Italian regional system: the unclear division of powers between the centre and the regions; weak intergovernmental relations; and the high degree of asymmetry in powers, administrative capacity, and political strength among the regions (Clementi 2020).

As regards the division of powers, the constitutional reform adopted in 2001 increased the role of the regions but also created a number of overlaps and potential conflicts; above all, it by no means enhanced the 'federal spirit' (Burgess 2012). Rather, in the political and academic debates, sentiments against regional autonomy are generally on the rise. As happened after the global financial crisis of 2009/10, the pandemic confirmed that the division of powers in Italy is not sound enough to resist a moment of crisis - indeed, Covid-19 has amplified the debate between those advocating greater centralisation and those supporting greater regional autonomy.

With regard to IGR, the absence of a territorial chamber and the structural weakness of the existing bodies for intergovernmental cooperation, notably the Permanent Conference, reduced regional involvement to a mere formality, with the state having appropriated all powers at the height of the emergency. At times like these when strong coordination is needed, the role of mechanisms that are effective in representing the voice of subnational entities becomes crucial. If the mechanisms are ineffective, as in the case of Italy, joint decisions simply become top-down impositions and the involvement of regions, a sham. The inefficiency of multilateral IGR mechanisms encourages the more powerful regions to engage in bilateral negotiations, thus accentuating the asymmetry inherent in the design of the territorial set-up and arousing jealousy among the regions.

Strong pre-existing de jure and de facto asymmetries among the Italian regions became ever more acute during the pandemic. Regional performance in tackling the emergency, especially in the area of health care, was mixed. Some regions fared extraordinarily well despite severe cuts over the past decade due to the debt-cutting policies, while others made serious mistakes, such as placing Covid-19 patients in elderly homes. Differences in performance were reflected in the political sphere, with some regional presidents increasing their popular support and others losing it in elections held in September 2020.

In sum, Covid-19 has placed the tensions between calls for further decentralisation and for re-centralisation under the spotlight. At the same time, ongoing reform processes stand to be significantly impacted, and their trajectory will not be the same as it would have been without the pandemic. The main pressure is 
no doubt for public health care to undergo a certain degree of re-centralisation. Even though most regions reacted well, the dominant discourse focuses on their large differences in terms of services, resources, and performance, and it is not unlikely that the opportunity will be seized to introduce stronger national control (Ciardo 2020). For some reason, the predominant sentiment in both politics and academia is the fear that regional differentiation might impair the equal protection of social rights.

Some reforms in the Italian regional system are indeed necessary, and the pandemic has made this all the more evident. As to the content of the reforms, however, opinions that were all but unanimous before the pandemic became ever more divided during it. These divisions of opinion will probably slow down, rather than speed up the necessary reforms and intensify, rather than subdue, conflicts between the centre and the territories.

\section{Note}

1 Sections 1.2.1, 1.2.2, 1.4.3, and 1.4.5 were written by Elisabeth Alber and Erika Arban; Section 1.2.3 by Paolo Colasante; Section 1.4.2 by Paolo Colasante and Adriano Dirri; Section 1.4.4 by Adriano Dirri; and Sections 1.3, 1.4.1, and 1.4.6 by Elisabeth Alber. The Introduction and section 1.5 were written by Francesco Palermo.

\section{References}

ANCI. 2020. Audizione informale presso le Commissioni Bilancio riunite, 28 maggio 2020.

Baldini, V. 2020. 'Riflessioni sparse sul caso (o sul caos) normativo al tempo dell'emergenza costituzionale', Dirittifondamentali.it, 2(1): 979-85.

Balduzzi, R. and D. Paris. 2018. 'La specialità che c'è, ma non si vede: la sanità nelle Regioni a statuto speciale', in F. Palermo and S. Parolari (eds), Le variabili della specialità: evidenze e riscontri tra soluzioni istituzionali e politiche settoriali, pp. 453-85, Napoli: Edizioni Scientifiche Italiane.

Banca d'Italia. 2020. Economie regionali, numero 22 - novembre 2020.

Boggero, G. 2020. 'Le "more” dell'adozione dei DPCM sono "ghiotte" per le Regioni: prime osservazioni sull'intreccio di poteri normativi tra Stato e Regioni in tema di Covid-19', Diritti Regionali, 21 March, 1: 362-7.

Burgess, Michael. 2012. In Search of the Federal Spirit. Oxford: Oxford University Press.

Capano, G. 2020. 'Policy design and state capacity in the COVID-19 emergency in Italy: if you are not prepared for the (un)expected, you can be only what you already are', Policy and Society, 39(3): 326-44.

Caretti, P. and G. Tarli Barbieri. 2012. Diritto Regionale, 3rd ed.Torino: Giappichelli.

Cerchi, R. and A. Deffenu. 2020. 'Fonti e provvedimenti dell'emergenza sanitaria Covid-19: prime riflessioni', Diritti Regionali, 23 April, 1: 648-78.

Clementi, F. 2020. 'Il lascito della gestione normativa dell'emergenza: tre riforme ormai ineludibili', Osservatorio Costituzionale 3: 33-47.

Ciardo, C. 2020. 'Il servizio sanitario nazionale alla prova dell'emergenza Covid-19: il rischio di una sanità diseguale', BioLaw Journal 2(Special Issue): 227-38.

Cicchetti, A. and A. Gasbarrini. 2016. 'The healthcare service in Italy: regional variability', European Review for Medical and Pharmacological Sciences, 20(1 Suppl.): 1-3. 
Cortese, F. 2020. 'Stato e Regioni alla prova del coronavirus', Le Regioni XLVIII(1): 3-10.

De Siano, A. 2020. 'Ordinanze sindacali e annullamento prefettizio ai tempi del Covid-19', Federalismi.it (Osservatorio emergenza Covid-19, no. 1), 15 April, https://www. federalismi.it/nv14/articolo-documento.cfm?Artid=41992.

Grazzini, L. et al. 2019. 'Asymmetric decentralization: some insights for the Italian case', Osservatorio Regionale sul Federalismo, Istituto Regionale Programmazione Economica Toscana, March, Nota 4.

Lavezzo, E. et al. 2020. 'Suppression of a SARS-CoV-2 outbreak in the Italian municipality of Vo', Nature, 584: 425-9.

Luciani, M. 2020. 'Il sistema delle fonti del diritto alla prova dell'emergenza', Rivista AIC, 2: 109-41.

Malo, M. 2020. 'Le Regioni e la pandemia: variazioni sul tema', Le Regioni XLVIII(1): 231-4.

Neri, S. 2019. 'The Italian National Health Service after the Economic Crisis: From Decentralization to Differentiated Federalism', E-Cadernos CES Online, 31/2019.

Nuti, S. et al. 2016. 'Making governance work in the health care sector: evidence from a "natural experiment" in Italy', Health Economics, Policy and Law, 11(1): 17-38.

OECD. 2010. Reviews of Risk Management Policies: Italy - Review of the Italian National Civil Protection System. Paris: OECD.

OECD. 2020. 'The Territorial Impact of COVID-19: Managing the Crisis across Levels of Government', 10 November.

Pignatelli N. 2020a. 'Il potere di annullamento straordinario ex art. 138 TUEL di un'ordinanza comunale: il Covid-19 non 'chiude' lo stretto di Messina', Diritti Regionali, September 1, 5: 68-82.

Pignatelli, N. 2020b. 'La specialità delle ordinanze dei sindaci nell'emergenza sanitaria nazionale: un potere 'inesauribile”, Diritti Regionali, 2/2020 (Special Issue): 69-85.

Raffiotta, E.C. 2020. Norme d'ordinanza: contributo a una teoria delle ordinanze emergenziali come fonti normative. Bologna: Bononia University Press.

Sabbioni, P. 2019. 'Art. 50 e 54 TUEL', in C. Napoli and N. Pignatelli (eds), Codice degli enti locali. Roma: Feltrinelli, $304 \mathrm{ff}$.

Scaccia, G. and C. D’Orazio. 2020. 'La concorrenza fra Stato e autonomie territoriali nella gestione della crisi sanitaria fra unitarietà e differenziazione', Forum di Quaderni Costituzionali, 3: 108-20.

Toth, F. 2014. 'How health care regionalisation in Italy is widening the North-South gap', Health Economics, Policy and Law, 9(3): 231-49. 